\title{
Seagrass responses to nutrient enrichment depend on clonal integration, but not flow-on effects on associated biota
}

\author{
Fernando Tuya ${ }^{1, *}$, María A. Viera-Rodríguez ${ }^{1}$, Rayco Guedes ${ }^{2}$, \\ Fernando Espino ${ }^{1}$, Ricardo Haroun ${ }^{1}$, Jorge Terrados ${ }^{3}$ \\ ${ }^{1}$ BIOGES, and ${ }^{2}$ Departamento de Química, Universidad de Las Palmas de Gran Canaria, 35017 Las Palmas, \\ Canary Islands, Spain \\ ${ }^{3}$ IMEDEA (CSIC-UIB), C/ Miquel Marquès 21, 07190 Esporles, Islas Baleares, Spain
}

\begin{abstract}
We determined physiological and morphological responses of the seagrass Cymodocea nodosa and associated epiphytes and epifauna to water column nutrient enrichment, and investigated whether responses were modulated by the clonal integration of the seagrass. Nutrient levels were elevated, relative to 'ambient' plots, in 'large' ( 10 to $100 \times)$ and 'moderate' ( $~ 5$ to $10 \times$ ) enrichment plots, in a seagrass meadow off the south coast of Gran Canaria. Clonal integration was severed in half the plots, isolating them from adjacent shoots. Seagrass shoot density, above-ground biomass and leaf surface were lower in fertilized than ambient plots when clonal integration was severed. In the plots where clonal integration was maintained, no differences in shoot density were observed between fertilized and ambient plots, while differences in aboveground biomass and leaf surface were exclusively observed between 'large' enrichment and 'ambient' plots. Seagrass above-ground tissues accumulated P, but not N, when clonal integration was maintained. The N content, but not P content, of below-ground parts increased with fertilization. The content of soluble sugars in seagrass tissues decreased under nutrient enrichment; this decay was, however, buffered when clonal integration was maintained. Grazing bites on leaves increased with nutrient enrichment regardless of the clonal integration. Epiphytic loads increased at elevated nutrient levels irrespective of the clonal integration. The abundance and richness of epifauna were larger on 'moderate' relative to 'ambient' and 'large' enrichment plots, independently of clonal integration. In conclusion, while the physiological and morphological responses of C. nodosa to nutrient enrichment depended on the maintenance of clonal integration, flow-on effects on epiphytes and epifauna were independent of the clonal integration of the seagrass.
\end{abstract}

KEY WORDS: Seagrass $\cdot$ Disturbance $\cdot$ Eutrophication $\cdot$ Stress $\cdot$ Clonality $\cdot$ Epibiota $\cdot$ Cymodocea nodosa $\cdot$ Canary Islands

Resale or republication not permitted without written consent of the publisher

\section{INTRODUCTION}

Seagrass meadows are one of the most productive marine habitats, providing high-value ecosystem services, which are the reason for their inclusion in different international conservation frameworks, such as the EU 92/43/CEE Habitats Directive (Hemminga \& Duarte 2000) and more recently into OSPAR
Convention (www.ospar.org). Conservation of these valuable habitats is therefore important, especially since seagrass meadows are in decline worldwide, particularly in areas of intense human disturbance (Hughes et al. 2009, Waycott et al. 2009).

Increases in the water column nutrient levels (eutrophication) along onshore areas, particularly urbanized metropolitan areas, have been identified 
as a key process negatively impacting seagrass meadows (Hughes et al. 2004, Burkholder et al. 2007, Cabaço et al. 2008, Antón et al. 2011). Nutrient enrichment facilitates the growth of seagrass epiphytes, phytoplankton and fast-growing macroalgae, reducing the amount of light reaching seagrass photosynthetic tissues (Tomasko \& Lapointe 1991, Short \& Wyllie-Echeverria 1996, Hauxwell et al. 2003, Hughes et al. 2004, Castejón-Silvo et al. 2012a), and indirectly can increase herbivory on heavily epiphytized seagrass parts, therefore decreasing the performance of seagrasses (Heck et al. 2006, Burkholder et al. 2007, Leoni et al. 2008, Bryars et al. 2011). Importantly, seagrasses show variation in their physiological responses to nutrient enrichment; inferences from one seagrass species from a particular site can be invalid not only for other seagrasses, but even for the same seagrass in different geographical settings (Burkholder et al. 2007).

Nutrient enrichment may not only alter recipient seagrasses and associated algae, but also affect the composition and abundance of associated faunal assemblages; experimental evidence of this is, however, rather sparse and mostly reduced to influences over key herbivores (Valentine \& Heck 2001, Castejón-Silvo et al. 2012b). Upward cascading effects of nutrient enrichment modify patterns in the composition and abundance of associated epifauna; epifaunal richness and abundance can increase, decrease or be unaltered with nutrient enrichment (Gil et al. 2006, Castejón-Silvo et al. 2012b). Nutrients may affect the nutritional quality (palatability) of seagrasses and associated algae as food for herbivores (Valentine \& Heck 2001, Goecker et al. 2005), as well as the quantity and quality of shelter provided by seagrasses for associated epifauna (Bostrom et al. 2002, Sterner \& Elser 2002, Gil et al. 2006, Antón et al. 2011). To understand the underlying processes leading to changes in the functional integrity of seagrass ecosystems as a result of eutrophication requires determining how seagrass responses are propagated into associated communities that find shelter and food within them (Attrill \& Depledge 1997), e.g. through habitat cascades (Thomsen et al. 2010).

Seagrasses are clonal plants and, therefore, nutrients and resources are redistributed between and within adjacent shoots; a relevant factor that can maintain seagrass performance during periods of high stress, such as after small-scale disturbances (Terrados et al. 1997, Marbá et al. 2002). The intensity of resource sharing, however, is well known to differ between seagrass species (Marbá et al. 2002). As a result, the physiological, morphological and ecological responses of seagrasses to small-scale disturbances may be dependent on the magnitude of clonal integration, a factor seldom considered in studies that have experimentally manipulated smallscale disturbances, e.g. nutrient enrichment, light reduction or burial (Tuya et al. 2013a).

The marine phanerogam Cymodocea nodosa (Ucria) Ascherson is distributed across the Mediterranean Sea and the adjacent eastern Atlantic coasts, including the archipelagos of Madeira and the Canaries (Mascaró et al. 2009). Subtidal meadows formed by C. nodosa are the dominant plant communities on shallow soft substrates throughout the Canaries (Barberá et al. 2005). They are mainly located along the eastern and southern coasts of the islands, where they provide food and shelter for diverse invertebrate and fish assemblages (Tuya et al. 2001, 2005, Espino et al. 2011). Meadows dominated by C. nodosa are susceptible to a range of human-mediated stressors (Oliva et al. 2012) that in recent years have significantly reduced the presence of this seagrass along some coastal stretches of the Canary Islands (Tuya et al. 2013b). The horizontal rhizomes of C. nodosa connect shoots a few meters apart; for this reason, the species is considered a good model for study of the effects of clonal integration on the physiology and ecology of seagrasses (Terrados et al. 1997, Nielsen \& Pedersen 2000, Tuya et al. 2013a).

In the present study, we experimentally assessed the physiological and morphological responses of the seagrass Cymodocea nodosa and its associated biota, including the composition and abundance of epiphytic and epifaunal assemblages, to short-term changes in the intensity of nutrient loads in the water column, determining whether responses could be modulated by the clonal integration of the plant. We expected increased nutrient availability to facilitate greater epiphytic loads on $C$. nodosa leaves that would cascade up to associated epifaunal assemblages, resulting in decreased seagrass aboveground density and biomass.

\section{MATERIALS AND METHODS}

\section{Experimental design}

This study was carried out in the center of a well-developed Cymodocea nodosa meadow (area $\sim 35 \mathrm{ha}, 900$ to 1200 shoots $\mathrm{m}^{-2}$, seagrass coverage 70 to $80 \%$; www.sebadales.org) located at 8 to $9 \mathrm{~m}$ depth off the south coast of Gran Canaria (N 27 $44.92^{\prime}$, $\left.\mathrm{W} 15^{\circ} 33.86^{\prime}\right)$. We manipulated nutrient levels in 
quadrangular plots $\left(80 \times 80 \mathrm{~cm}, \sim 0.6 \mathrm{~m}^{2}\right)$ set up on 2 seagrass patches (area $\sim 50 \mathrm{~m}^{2}$ ), located $150 \mathrm{~m}$ apart. Plots were subjected to 3 treatments: (1) addition of $\sim 1 \mathrm{~kg}$ of Osmocote ${ }^{\mathrm{TM}}$ slow-release fertilizer $(18 \%$ total N, $4.5 \% \mathrm{P}$ ) per plot (hereafter 'large enrichment plots'); (2) addition of $\sim 0.5 \mathrm{~kg}$ of fertilizer added per plot (hereafter 'moderate enrichment plots'); and (3) 'ambient plots', where no fertilizer was added. A $30 \mathrm{~cm}$ stake was hammered into the bottom in the center of each plot, and 4 additional stakes were secured $\sim 25 \mathrm{~cm}$ diagonally away from the central stake. The nutrients were added in 5 permeable (diffuser) bags per plot, one attached to each stake using cable ties. Bags were made from polyethylene mesh with a $1 \mathrm{~mm}$ mesh size; a semi-permeable membrane that allows a gradual release of nutrients (Worm et al. 2000, Bryars et al. 2011). In ambient plots, identical bags filled with sand acted as control treatments. Four plots of each treatment were randomly established at each seagrass patch; adjacent plots were at least 2 to $3 \mathrm{~m}$ apart to guarantee independence. At one of the 2 seagrass patches, all plots $(n=12)$ were left untouched, while all plots within the second patch were isolated from the adjacent shoots by sawing their clonal connection (i.e. horizontal rhizomes) around each plot down to $30 \mathrm{~cm}$ inside the seabed (Fig. S1 in the Supplement at www.int-res.com/ articles/suppl/m490p023_supp.pdf). The structure of the below-ground compartment (quantified as the below-ground biomass), determined at 2 random times before and after the experiment, did not differ between seagrass patches $(\mathrm{n}=4$; 2-way ANOVA, 'Patch': $F_{1,1}=10.75, \mathrm{p}=0.1885$; 'Patch $\times$ Times': $F_{1,44}=$ $0.03, \mathrm{p}=0.8533$ ), so responses to the manipulation of clonal integration were not confounded by potential differences between the 2 patches.

The experiment started on the 5 May 2011, and lasted $15 \mathrm{wk}$. This experimental duration was sufficient to detect responses, since epiphytes react rapidly to fertilization, and because the mobility of epifauna in seagrass meadows is very high (Leoni et al. 2008), particularly in the case of Cymodocea nodosa (Gartner et al. 2013). Bags containing either fertilizer or sand (control treatments) were replaced every $5 \mathrm{wk}$ to guarantee the effectiveness of the treatments (Worm et al. 2000, Bryars et al. 2011). Nutrient enrichment was measured by sampling water at $\sim 10 \mathrm{~cm}$ from bags in situ before replacing the bags and at the end of the experiment, i.e. after 5, 10 and $15 \mathrm{wk}$ ( $\mathrm{n}=3$ samples per treatment at each of 3 times). The water was filtered immediately on board and stored on ice until return to land. It was then frozen $\left(-20^{\circ} \mathrm{C}\right)$ until chemical analysis, when phosphate and nitrate concentrations were measured using an autoanalyzer. Two-way ANOVAs were used to test whether phosphate and nitrate concentrations differed among nutrient enrichment treatments (fixed factor with 3 levels) over time (random factor with 3 levels).

\section{Harvesting}

After 15 wk from the start of the experiment, 2 samples were destructively harvested from each experimental plot. First, we lowered an unbleached woven cotton bag over the seagrass canopy in a $20 \times 20 \mathrm{~cm}$ quadrat $\left(0.04 \mathrm{~m}^{2}\right)$ to sample epifauna, cutting the seagrass immediately above the sediment surface, and then closing the bag to retain the mobile fauna within (Brearley et al. 2008). Epifaunal samples were labelled and preserved in a $10 \%$ seawater formaldehyde solution. Second, a $50 \mathrm{~cm}$ long core $(20 \mathrm{~cm}$ inner diameter) was pushed by a SCUBA diver down to $\sim 25 \mathrm{~cm}$ into the sediment around the center of each experimental plot with the help of a hammer, to collect below- and above-ground seagrass material (i.e. leaves and rhizomes), which was transferred to a labeled bag. Samples were placed on ice until return to the lab and thereafter frozen until processing.

\section{Seagrass and epiphyte responses}

For each sample, we counted the number of shoots, the number of leaves per shoot and measured the length and width of 15 randomly selected seagrass leaves. We calculated individual leaf surface by multiplying length and width and summed these values up to obtain total leaf surface. We also counted the number of marks left by herbivore bites on every leaf, as an indirect way of estimating differences in herbivory among experimental treatments. Seagrass epiphytes were removed from 6 leaves using a razor blade and the composition (presence of epiphytic taxa) registered. All epiphytic material and their corresponding seagrass leaves were then dried $(24 \mathrm{~h}$ at $70^{\circ} \mathrm{C}$ ) and weighed; the epiphyte load was expressed as dry weight (DW) of epiphytes per $g$ DW of leaf biomass. All remaining seagrass material was further separated into above-ground (leaves) and belowground (rhizomes and roots) compartments, and subsequently oven-dried $\left(24 \mathrm{~h}\right.$ at $\left.70^{\circ} \mathrm{C}\right)$ to obtain DW biomass. Subsamples of dried leaves and rhizomes from each sample were rinsed in distilled water and then ground to a fine powder and subsequently analyzed for $\mathrm{N}$ and $\mathrm{P}$ content. $\mathrm{N}$ content was analyzed 
using a CHN analyzer. The $\mathrm{P}$ content was determined spectrophotometrically following combustion of leaf material for $3 \mathrm{~h}$ at $500^{\circ} \mathrm{C}$ and boiling the ash for $30 \mathrm{~min}$ in $0.2 \mathrm{~N} \mathrm{HCl}$ (Fourqurean et al. 1992). Soluble sugars (\% DW) from oven-dried leaves and rhizomes were determined following the anthrone method (Yemm \& Willis 1954). Briefly, sugars were twice extracted from pre-weighed samples, in $100 \%$ ethanol at $30^{\circ} \mathrm{C}$ and in $70 \%$ ethanol at $35^{\circ} \mathrm{C}$, and evaporated to dryness, redissolved in deionized water, and analyzed spectrophotometrically.

\section{Epifaunal identification}

Samples were decanted through a 0.5 mesh sieve. The fraction retained was separated into different taxonomical groups under a binocular microscope, and preserved in $70 \%$ ethanol. Macrofaunal specimens were determined to species level, whenever possible, by means of a binocular microscope, or by a LEICA DM LB microscope equipped with Nomarski interference. On some occasions, epifauna were sorted into broad taxonomic units to class/order level. The amount of leaf biomass (wet weight) was obtained for each sample.

\section{Statistical analyses}

Two-way permutation-based ANOVAs were used to test whether nutrient enrichment and the presence/absence of clonal integration interactively affected morphological responses of the seagrass, the internal contents of N, P and soluble sugars and the number of taxa and load of epiphytes. Nutrient enrichment and presence/absence of clonal integration were treated as fixed factors. Analyses were based on Euclidean distances, and p-values calculated from 4999 unrestricted permutations of the raw data (Anderson 2001). Pairwise comparisons (using 4999 permutations) were used, when appropriate, to resolve differences between levels of nutrient enrichment, either as an interaction (Fertilization $\times$ Clonal integration) or as a main effect. Differences in the total abundance and richness of epifauna were tested by 2-way permutation-based ANOVAs, using the same method, but including the leaf biomass of Cymodocea nodosa as a covariate to account for differences in the amount of available habitat between samples. For all ANOVAs, data were square-root or $\log (x+1)$ transformed to avoid heterogeneous variances whenever necessary. Canonical analysis of principal coordinates (CAP) was used as a constrained ordination procedure to test and visualize differences among the multivariate composition of epiphytes and the assemblage structure of epifauna among treatments. All multivariate data were square root transformed prior to analyses to downweight the most abundant taxa, and analyses based on Bray-Curtis dissimilarities. All multivariate procedures were carried out using the PRIMER 6.0 package.

\section{RESULTS}

\section{Experimental nutrient enrichment scenario}

Nutrient concentrations in the water column were larger $(\sim 10$ to $100 \times)$ immediately adjacent to large enrichment relative to ambient plots (Fig. 1). The

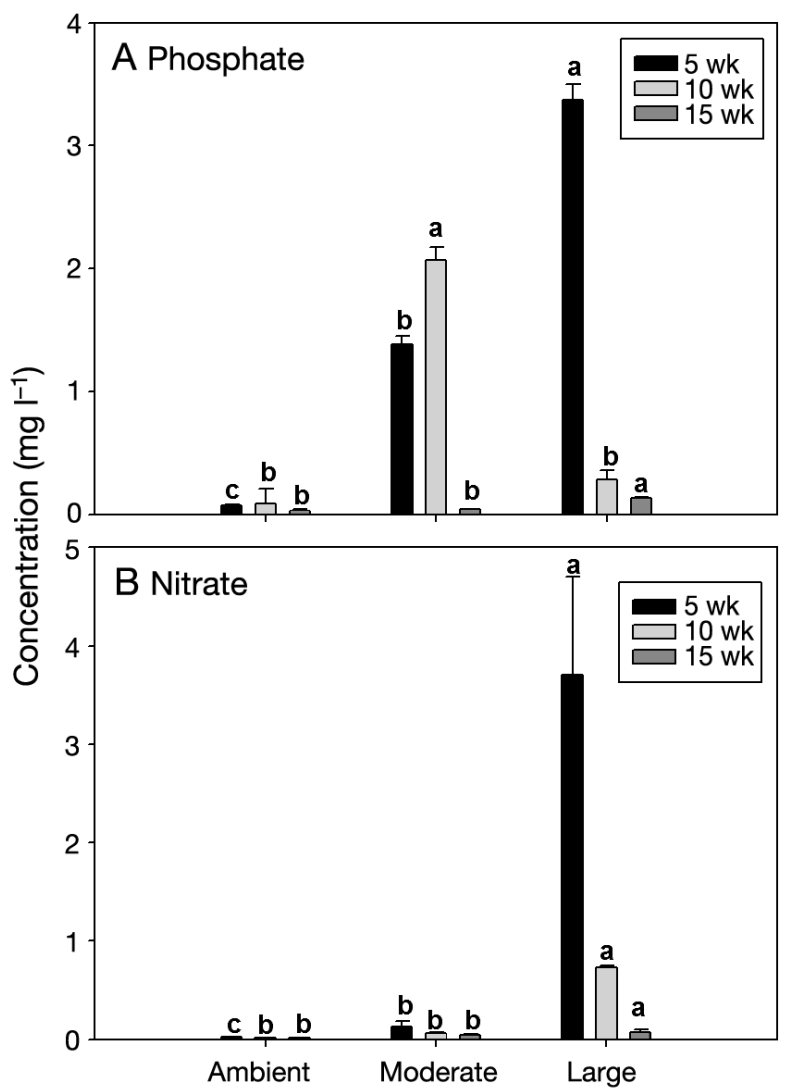

Fig. 1. Concentrations of (A) phosphate and (B) nitrate at $\sim 10 \mathrm{~cm}$ distance from permeable bags placed in fertilized and ambient plots to investigate seagrass responses to experimental fertilization. In 'large' enrichment plots, 5 bags containing a total of $\sim 1 \mathrm{~kg}$ of slow-release fertilizer were placed in each plot. In 'moderate' enrichment plots, $\sim 0.5 \mathrm{~kg}$ of fertilizer was added per plot. In 'ambient' plots, bags were filled with sand as control treatments. Bars show mean $+\mathrm{SE}(\mathrm{n}=3)$ of samples collected at 5, 10 or $15 \mathrm{wk}$ after start of the experiment. Different letters above bars denote significant differences among treatments; comparisons are shown separately for each time 
magnitude of differences in phosphate and nitrate concentrations among nutrient enrichment treatments, however, varied through time, and resulted in a significant statistical interaction (phosphate: $F_{4,18}=$ 401.25, nitrate: $F_{4,18}=36908.7 ; \mathrm{p}<0.01$ in both cases) between treatments and times (see Fig. 1 for significant pairwise differences among treatments at each time that measurements were made). Phosphate was also larger immediately adjacent to moderate enrichment relative to ambient plots at 2 times, but nitrate exclusively at 1 time (Fig. 1).

\section{Seagrass performance: morphological responses}

Nutrient enrichment caused an array of seagrass morphological responses. Fig. 2 shows morphological responses to nutrient enrichment, and responses



Fig. 2. Cymodocea nodosa. Seagrass morphological responses after 15 wk exposure to experimental fertilization treatments (see Fig. 1 legend for details) in plots with and without clonal integration. In "- clonal integration" plots, plants were isolated from adjacent shoots by sawing their clonal connection (i.e. horizontal rhizomes) around each plot down to $30 \mathrm{~cm}$ inside the seabed. Bars show mean $+\mathrm{SE}(\mathrm{n}=4)$ under the same nutrient conditions with and without clonal integration, for shoot density, above- and below-ground biomass, leaf surface and leaves per shoot. The effects of fertilization over descriptors of the above-ground parts, including seagrass shoot density (Fig. 2A), above-ground biomass (Fig. 2B) and leaf surface (Fig 2D), were dependent on whether clonal integration was maintained (ANOVA, Fert. $\times$ Clonal Int.: $\mathrm{p}<0.05$; Table 1). Seagrass shoot density was significantly lower in moderate and large enrichment than in ambient plots when clonal integration was eliminated; whereas no significant differences were observed when clonal integration was maintained (Fig. 2A; pairwise comparisons, Table 1). Likewise a slight increase in shoot density was observed at moderate enrichment plots when clonal integration was maintained (Fig. 2A). Seagrass above-ground biomass and leaf surface were also significantly lower in moderate and large enrichment than in ambient plots when the clonal integration was severed; whereas, when clonal integration was maintained, lower above-ground biomass and leaf surface compared to ambient plots occurred exclusively in large enrichment plots (Fig. 2B,D; pairwise comparisons, Table 1). Seagrass belowground biomass did not significantly change among experimental treatments (Fig. 2C) (ANOVA, all terms: $\mathrm{p}>0.05$; Table 1). The number of leaves per shoot was also unaffected by treatments (Fig. 2E) (ANOVA, all terms: $\mathrm{p}>0.05$; Table 1 ).

\section{Seagrass performance: physiological responses}

Fig. 3 shows nutrient levels $(\mathrm{N}, \mathrm{P}$ and soluble sugars) in response to nutrient enrichment, and under the same nutrient conditions with and without clonal integration, for aboveand below-ground tissues. The belowground internal $\mathrm{N}$ content increased in large enrichment plots when clonal integration was maintained, but not when it was severed (Fig. 3A) (ANOVA, Fert. $\times$ Clonal Int.: $p=0.0086$; pairwise comparisons, Table 1). The content of $\mathrm{N}$ did not change among 
Table 1. Cymodocea nodosa. Results of 2-way permutation-based ANOVAs testing the effects of 'Fertilization' (fixed factor) and 'Clonal Integration' (fixed factor) on seagrass morphological and physiological responses after 15 wk exposure to experimental fertilization in plots with and without clonal integration. Significant $p$-values $(p<0.05)$ are shown in bold. Pairwise comparisons are included for significant 'Fert. $\times$ Clonal Int.' interactions; i.e. significant differences between fertilization treatments (large $[\mathrm{L}]$, moderate $[\mathrm{M}]$ and ambient[A]) for plots where clonal integration was maintained or severed

\begin{tabular}{|c|c|c|c|c|c|}
\hline & $\mathrm{df}$ & MS & $F$ & $\mathrm{p}$ & $\begin{array}{l}\text { Pairwise comparisons for the } \\
\text { 'Fert. } \times \text { Clonal Int.' interaction term }\end{array}$ \\
\hline \multicolumn{6}{|l|}{ Shoot density } \\
\hline Fertilization & 2 & 89.51 & 3.31 & 0.0314 & \\
\hline Clonal Int. & 1 & 24.00 & 0.88 & 0.3868 & \\
\hline Fert. $\times$ Clonal Int. & 2 & 97.12 & 3.59 & 0.0271 & - Clonal Int.: $\mathrm{L}=\mathrm{M}<\mathrm{A}_{i}+$ Clonal Int.: - \\
\hline Residual & 18 & 27 & & & \\
\hline \multicolumn{6}{|c|}{ Above-ground biomass } \\
\hline Fertilization & 2 & 8.65 & 11.54 & 0.0002 & \\
\hline Clonal Int. & 1 & 1.26 & 1.68 & 0.2260 & \\
\hline Fert. $\times$ Clonal Int. & 2 & 2.74 & 3.65 & 0.0238 & - Clonal Int.: $\mathrm{L}=\mathrm{M}<\mathrm{A}_{i}+$ Clonal Int.: $\mathrm{L}<\mathrm{A}$ \\
\hline Residual & 18 & 0.74 & & & \\
\hline \multicolumn{6}{|c|}{ Below-ground biomass } \\
\hline Fertilization & 2 & 15.28 & 1.80 & 0.1901 & \\
\hline Clonal Int. & 1 & 7.925 & 0.93 & 0.3522 & \\
\hline Fert. $\times$ Clonal Int. & 2 & 9.73 & 1.14 & 0.3352 & \\
\hline Residual & 18 & 8.48 & & & \\
\hline \multicolumn{6}{|l|}{ Leaves per shoot } \\
\hline Fertilization & 2 & 0.26 & 0.69 & 0.5296 & \\
\hline Clonal Int. & 1 & 1.27 & 3.25 & 0.0930 & \\
\hline Fert. $\times$ Clonal Int. & 2 & 0.38 & 0.98 & 0.3968 & \\
\hline Residual & 18 & 0.39 & & & \\
\hline \multicolumn{6}{|l|}{ Leaf surface } \\
\hline Fertilization & 2 & $3.02 \times 10^{6}$ & 2.42 & 0.0128 & \\
\hline Clonal Int. & 1 & $4.74 \times 10^{5}$ & 0.38 & 0.7874 & \\
\hline Fert. $\times$ Clonal Int. & 2 & $3.37 \times 10^{6}$ & 2.69 & 0.0412 & - Clonal Int.: $\mathrm{L}=\mathrm{M}<\mathrm{A}_{i}+$ Clonal Int.: $\mathrm{L}<\mathrm{A}$ \\
\hline Residual & 18 & $1.25 \times 10^{6}$ & & & \\
\hline \multicolumn{6}{|c|}{ Bites per leaf biomass } \\
\hline Fertilization & 2 & 7.24 & 1.20 & 0.3388 & \\
\hline Clonal Int. & 1 & 0.57 & 0.09 & 0.7548 & \\
\hline Fert. $\times$ Clonal Int. & 2 & 2.14 & 0.35 & 0.7194 & \\
\hline Residual & 18 & 6.030 & & & \\
\hline \multicolumn{6}{|c|}{ N content (above-ground tissues) } \\
\hline Fertilization & 2 & 0.37 & 1.95 & 0.1584 & \\
\hline Clonal Int. & 1 & 0.12 & 0.58 & 0.4966 & \\
\hline Fert. $\times$ Clonal Int. & 2 & 0.18 & 0.95 & 0.4294 & \\
\hline Residual & 18 & 0.19 & & & \\
\hline \multicolumn{6}{|c|}{$\mathbf{N}$ content (below-ground tissues) } \\
\hline Fertilization & 2 & 1.61 & 6.61 & 0.0028 & \\
\hline Clonal Int. & 1 & 3.95 & 16.16 & 0.0002 & \\
\hline Fert. $\times$ Clonal Int. & 2 & 1.42 & 5.80 & 0.0086 & - Clonal Int.: $\mathrm{L}>\mathrm{M}=\mathrm{A}_{i}+$ Clonal Int.: - \\
\hline Residual & 18 & 0.24 & & & \\
\hline \multicolumn{6}{|c|}{ P content (above-ground tissues) } \\
\hline Fertilization & 2 & $9.9 \times 10^{-5}$ & 4.62 & 0.0143 & \\
\hline Clonal Int. & 1 & $3.01 \times 10^{-3}$ & 140.56 & 0.0012 & \\
\hline Fert. $\times$ Clonal Int. & 2 & $7.94 \times 10^{-4}$ & 37.05 & 0.0012 & - Clonal Int.: $\mathrm{L}=\mathrm{M}<\mathrm{A}_{i}+$ Clonal Int.: $\mathrm{L}>\mathrm{A}$ \\
\hline Residual & 18 & $2.14 \times 10^{-5}$ & & & \\
\hline \multicolumn{6}{|c|}{$P$ content (below-ground tissues) } \\
\hline Fertilization & 2 & $3.08 \times 10^{-5}$ & 7.81 & 0.0040 & \\
\hline Clonal Int. & 1 & $2.56 \times 10^{-5}$ & 6.50 & $\mathbf{0 . 0 1 8 4}$ & \\
\hline Fert. $\times$ Clonal Int. & 2 & $1.37 \times 10^{-4}$ & 34.77 & 0.0011 & - Clonal Int.: -; + Clonal Int.: L < A \\
\hline Residual & 18 & $3.94 \times 10^{-6}$ & & & \\
\hline
\end{tabular}


Table 1 (continued)

\begin{tabular}{|c|c|c|c|c|c|}
\hline & df & MS & $F$ & $\mathrm{p}$ & $\begin{array}{l}\text { Pairwise comparisons for the } \\
\text { 'Fert. } \times \text { Clonal Int.' interaction term }\end{array}$ \\
\hline \multicolumn{6}{|c|}{ Soluble sugars (above-ground tissues) } \\
\hline Fertilization & 2 & 0.505 & 173.42 & 0.0002 & \\
\hline Clonal Int. & 1 & $2.04 \times 10^{-2}$ & 7.01 & 0.0094 & \\
\hline Fert. $\times$ Clonal Int. & 2 & 0.24 & 84.36 & 0.0002 & $\begin{array}{l}\text { - Clonal Int.: } \mathrm{L}=\mathrm{M}<\mathrm{A} \\
\text { + Clonal Int.: } \mathrm{L}=\mathrm{M}=\mathrm{A}\end{array}$ \\
\hline Residual & 18 & $2.91 \times 10^{-3}$ & & & \\
\hline \multicolumn{6}{|c|}{ Soluble sugars (below-ground tissues) } \\
\hline Fertilization & 2 & 8.50 & 787.56 & 0.0002 & \\
\hline Clonal Int. & 1 & $4.80 \times 10^{-2}$ & 4.44 & 0.0711 & \\
\hline Fert. $\times$ Clonal Int. & 2 & $7.85 \times 10^{-5}$ & $7.27 \times 10^{-3}$ & 0.9936 & \\
\hline Residual & 18 & $1.08 \times 10^{-2}$ & & & \\
\hline
\end{tabular}

experimental factors for seagrass above-ground compartments (Fig. 3B) (ANOVA, all terms: p > 0.05; Table 1). For seagrass below-ground compartments, no significant difference in the internal P content was
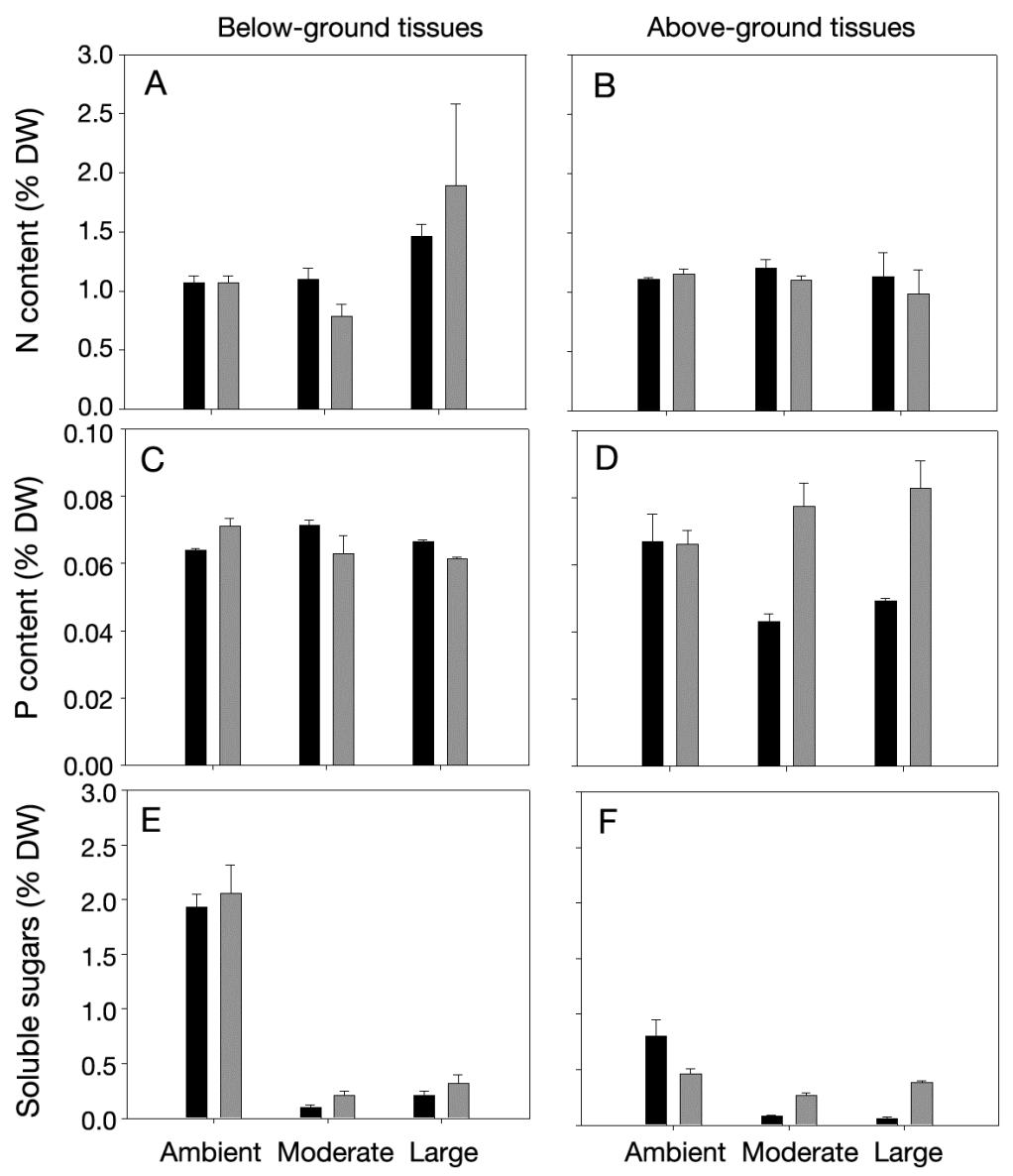

- Clonal integration $\longleftarrow+$ Clonal integration

Fig. 3. Cymodocea nodosa. Seagrass tissue contents: $(A, B) N,(C, D) P$ and $(\mathrm{E}, \mathrm{F})$ soluble sugars, after $15 \mathrm{wk}$ exposure to experimental fertilization treatments in plots with and without clonal integration (see Figs. 1 \& 2 legends for details). Bars show mean $+\mathrm{SE}(\mathrm{n}=4)$ observed among fertilization treatments when the clonal integration was severed, whereas the P content was larger in ambient than large enrichment plots when the clonal integration was maintained (Fig. 3C) (ANOVA, Fert. $\times$ Clonal Int.: $\mathrm{p}=$ 0.0011; pairwise comparisons, Table 1). The content of $\mathrm{P}$ increased with nutrient enrichment for seagrass above-ground parts when clonal integration was maintained, but decreased when clonal integration was severed (Fig. 3D) (ANOVA, Fert. $\times$ Clonal Int.: $\mathrm{p}=0.0012$; pairwise comparisons, Table 1). The content of soluble sugars in seagrass below-ground tissues decreased under large and moderate enrichment irrespective of clonal integration (Fig. 3E) (ANOVA, Fertilization: $\mathrm{p}=0.0002$, Fert. $\times$ Clonal Int.: $\mathrm{p}=$ 0.99; Table 1); this decrease was, however, particularly noticeable when clonal integration was severed (Fig. 3E). The content of soluble sugars in aboveground seagrass tissues decreased markedly under fertilization when clonal integration was severed, but decreased slightly when clonal integration was maintained (Fig. 3F) (ANOVA, Fert. $\times$ Clonal Int.: $\mathrm{p}=0.0002$; pairwise comparisons, Table 1).

\section{Grazing on seagrass leaves}

The number of grazing bites on aboveground seagrass material tended to increase with nutrient enrichment (Fig. 4). However, a great variability from plot to plot within each treatment precluded de- 


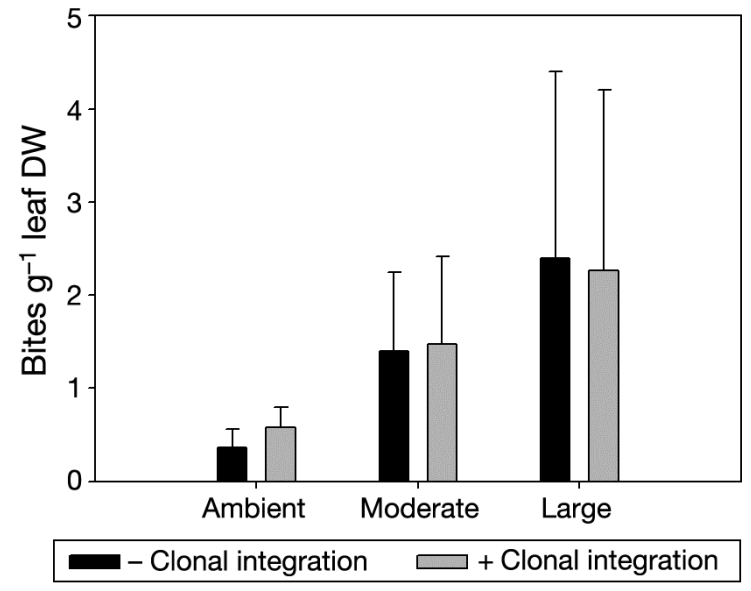

Fig. 4. Intensity of grazing on seagrass leaves after $15 \mathrm{wk}$ exposure to experimental fertilization treatments in plots with and without clonal integration (see Figs. 1 \& 2 legends for details). Bars show mean $+\mathrm{SE}(\mathrm{n}=4)$

tec-tion of significant differences (ANOVA, Fertilization: $\mathrm{p}=0.3388$, Fert. $\times$ Clonal Int.: $\mathrm{p}=0.7194$; Table 1 ).

\section{Epiphyte responses}

A total of 33 epiphytic taxa were identified on seagrass leaves (Table S1 in the Supplement). Elevated nutrients significantly increased epiphytic loads in nutrient enriched (moderate and large) relative to ambient plots, irrespective of clonal integration (Fig. 5A) (ANOVA, Fertilization: $p=0.039$, Fert. $\times$ Clonal Int.: $\mathrm{p}=0.579$; Table 2). Significantly larger numbers of epiphytic taxa were found in nutrient enriched relative to ambient plots, irrespective of clonal integration (Fig. 5B) (ANOVA, Fertilization: $p=0.0004$, Fert. $\times$ Clonal Int.: $p=0.454$; Table 2 ). This resulted in significant differences in epiphytic composition among fertilization treatments: the CAP ordination separated epiphytic assemblages, particularly epiphytes growing on ambient seagrass leaves, from those on moderate and large enriched nutrient plots along the first canonical axis (Fig. 6A, $\delta_{1}{ }^{2}=0.6889, \mathrm{p}<0.01$ ).

\section{Epifaunal responses}

A total of 96 epifaunal organisms, belonging to 22 taxa, were counted (Table S2 in the Supplement). The total abundance and species richness of epifauna were larger in moderate enrichment plots than in ambient and large enrichment plots (Fig. 7A,B) (ANOVA, Fertilization: $\mathrm{p}=0.05$ for both total abundances and richness of epifauna; pairwise comparisons, Table 2), but were not affected by clonal inte-

Table 2. Cymodocea nodosa. Results of 2-way uni- and multivariate ANOVAs testing the effects of 'Fertilization' (fixed factor) and 'Clonal Integration' (fixed factor) on biota responses after 15 wk exposure to experimental fertilization in plots with and without clonal integration. Significant $p$-values $(p<0.05)$ are shown in bold. Pairwise comparisons are included for differences between fertilization treatments (large, moderate and ambient)

\begin{tabular}{|c|c|c|c|c|c|}
\hline & $\mathrm{df}$ & MS & $F$ & $\mathrm{p}$ & Pairwise comparisons \\
\hline \multicolumn{6}{|l|}{ Epiphytic load } \\
\hline Fertilization & 2 & 0.3408 & 7.67 & 0.0039 & \multirow[t]{4}{*}{ Large $=$ Moderate $>$ Ambient } \\
\hline Clonal Int. & 1 & 0.0147 & 0.33 & 0.5722 & \\
\hline Fert. $\times$ Clonal Int. & 2 & 0.025 & 0.56 & 0.5798 & \\
\hline Residual & 18 & 0.0444 & & & \\
\hline \multicolumn{5}{|l|}{ Epiphytic composition } & \multirow[t]{5}{*}{ Large $=$ Moderate $\neq$ Ambient } \\
\hline Fertilization & 2 & 32.666 & 12.4412 & 0.0004 & \\
\hline Clonal Int. & 1 & 26.041 & 9.9211 & 0.0551 & \\
\hline Fert. $\times$ Clonal Int. & 2 & 2.166 & 0.8306 & 0.4540 & \\
\hline Residual & 18 & 2.625 & & & \\
\hline \multicolumn{6}{|l|}{ Epifaunal total abundance } \\
\hline Covariate (leaf wet weight biomass) & 2 & 51.155 & 7.1992 & 0.0244 & \multirow{5}{*}{ Moderate $>$ Large $=$ Ambien } \\
\hline Fertilization & 2 & 25.451 & 3.5817 & 0.0516 & \\
\hline Clonal Int. & 1 & 6.446 & 0.9072 & 0.3516 & \\
\hline Fert. $\times$ Clonal Int. & 2 & 3.413 & 0.4804 & 0.6276 & \\
\hline Residual & 16 & 7.105 & & & \\
\hline \multicolumn{6}{|l|}{ Epifaunal richness } \\
\hline Covariate (leaf wet weight biomass) & 2 & 14.858 & 5.6219 & 0.0342 & \multirow{5}{*}{ Moderate $>$ Large $=$ Ambien } \\
\hline Fertilization & 2 & 9.226 & 3.4912 & 0.0586 & \\
\hline Clonal Int. & 1 & 2.326 & 0.8809 & 0.3751 & \\
\hline Fert. $\times$ Clonal Int & 2 & 0.674 & 0.2550 & 0.7892 & \\
\hline Residual & 16 & 2.643 & & & \\
\hline
\end{tabular}




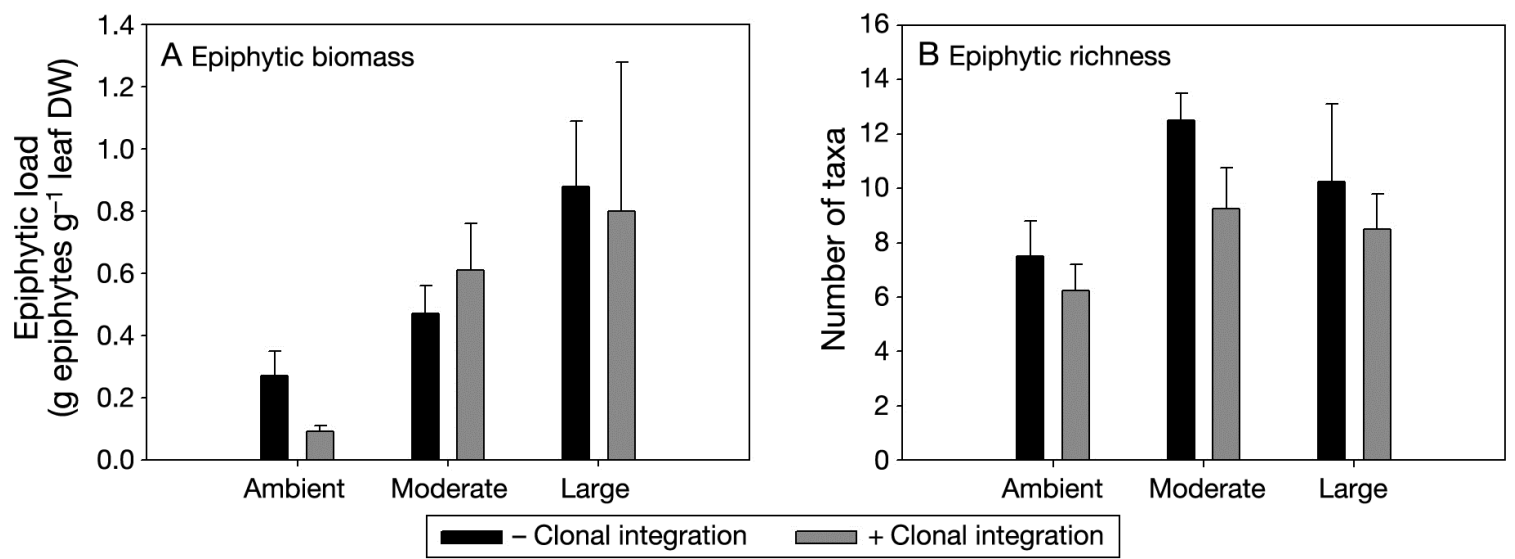

Fig. 5. (A) Epiphytic load and (B) total number of epiphyte taxa on seagrass after 15 wk exposure to experimental fertilization in plots with and without clonal integration (see Figs. 1 \& 2 legends for details). Bars show mean $+\mathrm{SE}(\mathrm{n}=4)$
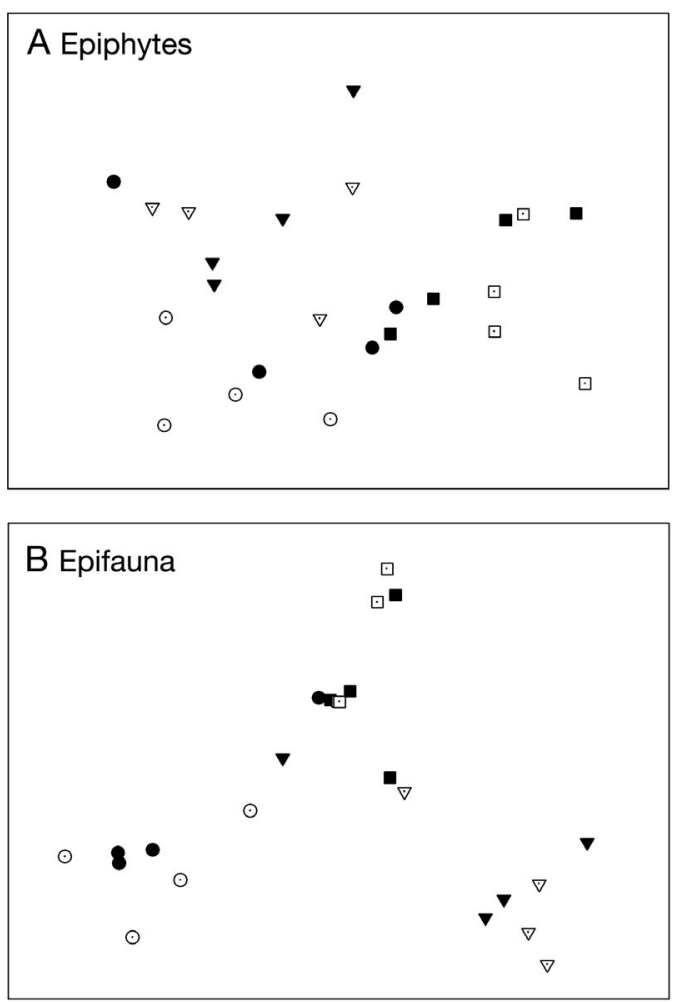

- Large - Clonal integration

- Large + Clonal integration

$\checkmark$ Moderate - Clonal integration

$\nabla$ Moderate + Clonal integration

- Ambient - Clonal integration

$\square$ Ambient + Clonal integration

Fig. 6. Constrained canonical ordination (CAP) of (A) epiphytic composition and (B) epifaunal assemblage structure on seagrass after $15 \mathrm{wk}$ exposure to experimental fertilization in plots with and without clonal integration (see Figs. 1 \& 2 legends for details), showing similarities between treatments
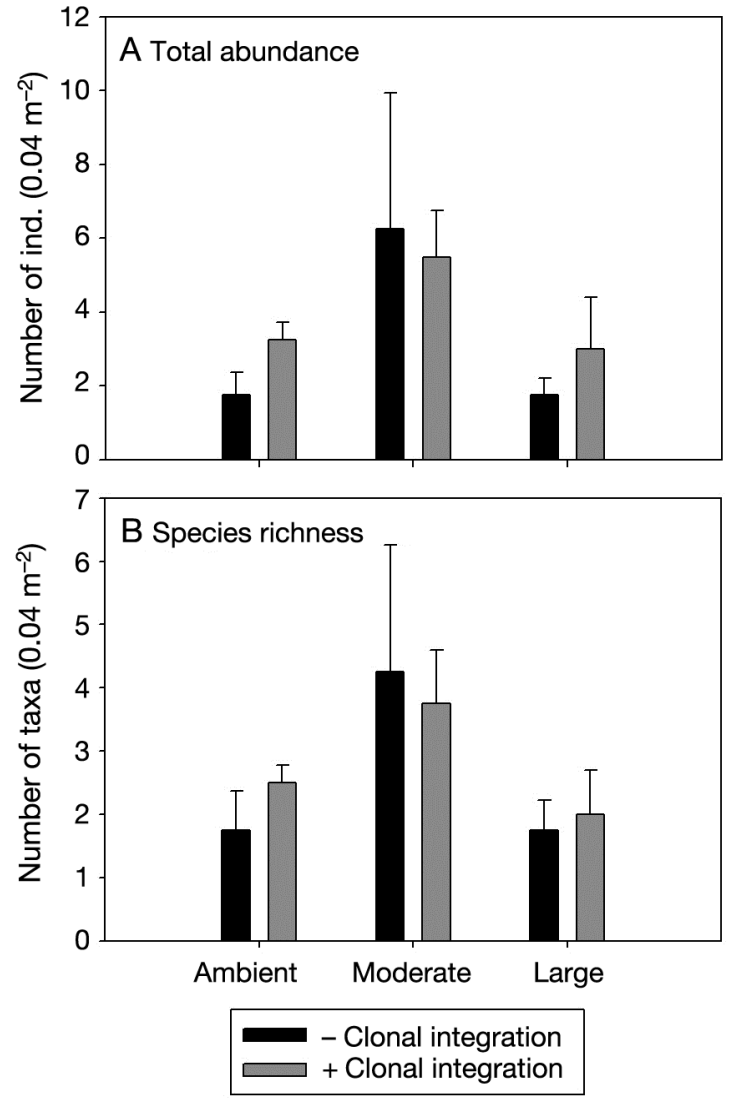

Fig. 7. Epifaunal (A) total abundance and (B) species richness after $15 \mathrm{wk}$ exposure to experimental fertilization in plots with and without clonal integration (see Figs. 1 \& 2 legends for details). Bars show mean $+\mathrm{SE}(\mathrm{n}=4)$

gration. The CAP analysis efficiently separated epifaunal assemblages, particularly those in moderate enrichment plots from those in large enrichment and ambient plots, along the first canonical axis (Fig. 6B, $\delta_{1}{ }^{2}=0.7761, \mathrm{p}<0.01$ ). 


\section{DISCUSSION}

\section{Seagrass and epiphyte responses}

Several studies have established a connection between seagrass loss with a large increase of nutrients in the water column, either through experiments or observational approaches. Nutrient increases typically occur as a result of human-mediated sources, e.g. through domestic sewage outfalls, aquaculture facilities, and coastal run-off (see reviews by Hughes et al. 2004, Burkholder et al. 2007, Leoni et al. 2008). Our results have shown that enhanced water column nutrients caused a significant decrease in seagrass above-ground tissues and a concurrent increase in epiphytic loads, including a change in epiphytic composition, on Cymodocea nodosa leaves. Fastgrowing epiphytes can rapidly assimilate water column nutrients (Duarte 1995). As a result, the amount of light reaching seagrass photosynthetic compartments might have been seriously reduced. Moreover, nitrate assimilation and reduction are energetically costly bio-chemical processes, promoting declines in plant growth, and leading to an overall decrease in carbohydrate contents and to internal C-limited conditions (Burkholder et al. 1992, 1994, Touchette et al. 2003). In our study, these internal imbalances in $C$ metabolism likely caused suffocation and energetic exhaustion of the seagrass, which was demonstrated through drastically reduced concentrations of soluble sugars in plant tissue under nutrient enriched conditions. Similarly, severe reductions in light levels induced by epiphytic overgrowth have been described to cause a decrease in seagrass shoot density, canopy height, rates of photosynthesis and nutrient uptake, significantly contributing to seagrass declines (e.g. Tomasko \& Lapointe 1991, Hauxwell et al. 2003, Hughes et al. 2004, Cabaço et al. 2008, Leoni et al. 2008, Bryars et al. 2011). In our study, epiphytic loads were visually larger on the mid and upper parts of $C$. nodosa leaves, whereas the lower parts were mostly unaffected by epiphytes; this might have caused increased necrosis and breaking of seagrass leaves. Hence, leaves became shorter within fertilized plots, possibly because the amount of epiphytemediated sloughing of old leaf material increased, as has been described for the seagrasses Posidonia sinuosa (Bryars et al. 2011) and P. oceanica (Castejón-Silvo et al. 2012a) under similar experimental fertilization.

An additional mechanism might have also accelerated the removal of seagrass above-ground parts in fertilized plots: grazing of leaves by large herbivores due to an increase in the epiphyte load on leaves (Prado et al. 2010, Marco-Méndez et al. 2012). This was suggested by an increase in the average number of bites on leaves on fertilized compared to ambient plots; however, differences were not statistically significant. Most likely, fertilization enhanced the palatability of seagrass leaves through larger epiphytic biomass. Such a pattern was observed for fish grazing on Posidonia oceanica leaves (Prado et al. 2010). In the study region, the parrotfish Sparisoma cretense is a conspicuous omnivorous living in Cymodocea nodosa seagrass meadows, where it is found both as large-sized adults and small-sized juveniles, reaching abundances that typically range between 0.5 to 4 ind. $100 \mathrm{~m}^{-2}$ (Tuya et al. 2005, Espino et al. 2011); this species likely consumes seagrass material in the study area (González 1990). A sibling fish, the bucktooth parrotfish $S$. radians, has been found to cause relevant reductions in aboveground material of the seagrass Thalassia testudinum in Florida (Goecker et al. 2005), where seagrass herbivores consume larger quantities of epiphytized seagrass leaves than of epiphyte-free leaves (Marco-Méndez et al. 2012).

Higher nutrient concentrations in the environment are generally connected with higher nutrient contents in plant tissues (Udy \& Dennison 1997). In this sense, increased $\mathrm{N}$ and $\mathrm{P}$ content in leaves as a consequence of water column nutrient enrichment has been described for seagrasses (Burkholder et al. 2007, Cabaço et al. 2008), including Cymodocea nodosa in the Mediterranean (Oliva et al. 2012). Leaf $\mathrm{N}$ content, however, can be highly variable, limiting its usefulness during the early stages of eutrophication, and varying according to site-specific features and specific seagrass requirements (Lee et al. 2004). In the present study, the increase in the $\mathrm{N}$ content of C. nodosa below-ground compartments under large nutrient enrichment suggests an internal translocation of $\mathrm{N}$ from the senescent above-ground tissue into the storage organs (rhizomes). This type of translocation is a survival mechanism, helping the plant to recover when the stressor is removed after a period of time (Cabaço \& Santos 2007). Indeed, the increase in below-ground biomass under large nutrient enrichment when clonal integration is maintained could be supported by such an increase in $\mathrm{N}$. The increase in the content of $\mathrm{P}$ in $C$. nodosa foliar tissues with fertilization fits previous observations of responses to fertilization when clonal integration is not severed, by $C$. nodosa in Mediterranean waters (Oliva et al. 2012) and other seagrasses (Leoni et al. 2008). The decrease in the leaf content of $\mathrm{P}$ with nutrient enrich- 
ment when the clonal connection was severed, however, suggests that leaves were not able to take advantage of the increase in $\mathrm{P}$ in the water column. Such a contrasting pattern indicates that severing the clonal integration of the plant affects the capacity of shoots to gain and further mobilize P to other seagrass compartments. The expected increase in the content of $\mathrm{P}$ in the below-ground sections of $C$. nodosa when clonal integration is maintained is most likely masked by the synthesis of new below-ground biomass with fertilization.

Previous experimental studies manipulating in situ water column nutrient loads have assumed that clonal integration of seagrass material within plots does not affect seagrass responses, though there has been speculation about its potential confounding effect on seagrass responses (Bryars et al. 2011). Importantly, in our study, the magnitude of seagrass decline as a result of fertilization was dependent on the maintenance of clonal integration. We have thus demonstrated that, when clonal integration was maintained, seagrasses were able to draw on reserves from adjacent shoots to overcome the stress caused by fertilization. This was demonstrated by the larger concentrations of soluble sugars found in seagrass compartments, particularly leaves, under fertilization when clonal integration was maintained. Clonal integration allows shoots situated along the same rhizome to exchange nutrients and resources in a clear source-sink gradient (Nielsen \& Pedersen 2000). Translocation of resources from non-disturbed, healthy, shoots to adjacent disturbed shoots is, in turn, a mechanism that increases resistance of seagrasses to disturbances (Terrados et al. 1997, Marbá et al. 2002); this translocation mechanism seems to be responsible for the maintenance of seagrass aboveground parts in fertilized plots when clonal integration was not severed.

\section{Epifaunal responses}

Epifaunal assemblages are prominent elements of seagrass habitats that control algal growth on seagrasses (Heck \& Valentine 2007). Defaunated artificial units mimicking seagrasses are rapidly colonized by a suite of epifaunal organisms within a Cymodocea nodosa meadow in the study region (Gartner et al. 2013). Our study detected an increase in epifaunal richness and abundance in experimental plots in response to a moderate increase in water column nutrients, irrespective of whether the clonal connection was maintained or eliminated. This outcome is potentially the result of a trade-off between 2 interactive processes. On the one hand, seagrasses within fertilized plots had a larger epiphyte load than in controls; so nutrient enrichment caused an increase in the amount of epiphytes available as food for mesograzing epifauna, e.g. amphipods, isopods and prosobranch grazers, which preferentially feed on epiphytes rather than seagrass leaves because of their larger nutritional value (Bostrom et al. 2002, Gil et al. 2006). This reinforces the idea that epiphytes are an essential resource for higher trophic levels of seagrass food webs, benefitting both epifaunal resident populations and potential colonizers from adjacent areas (Castejón-Silvo et al. 2012b). Although we did not measure structural ( $\mathrm{N}$ and $\mathrm{P}$ ) contents in epiphytes, it is plausible that epiphytes increased their nutritional quality, and so their palatability for mesograzing epifauna under fertilized conditions (Sterner \& Elser 2002, Antón et al. 2011). On the other hand, an abrupt reduction in the amount of above-ground seagrass parts within large enrichment plots likely reduced the amount of shelter seagrasses available to epifauna, which explains the reduction in epifaunal richness and abundance in large relative to moderate enrichment plots. Such a response has also been experimentally observed when seagrasses are subjected to high levels of other environmental stressors, e.g. light reduction (Gardner et al. 2010). Our results, therefore, fit previous observations of an increase in faunal richness and density under a scenario of moderate nutrient enrichment that favors food availability for epifauna; however, degradation of the primary producer providing biogenic habitat under a large nutrient enrichment scenario overpowers any enhancement caused by food availability (Gil et al. 2006, Antón et al. 2011).

\section{CONCLUSIONS}

A $15 \mathrm{wk}$ increase in sea-water column nutrients reduced the above-ground biomass of Cymodocea nodosa; this decline was exacerbated where $C$. nodosa below-ground sections were isolated from adjacent, undisturbed, shoots, i.e. by lack of clonal integration. Nutrient enrichment increased epiphytic loads, irrespective of whether the clonal integration of the plant was severed or maintained. Flow-on cascading effects on seagrass epifauna led to increased faunal richness and abundance under a moderate nutrient enrichment, irrespective of whether the clonal integration of the plant was severed or maintained. As a result, the physiological and morpho- 
logical responses of $C$. nodosa to fertilization depended on the clonal integration of the plant, whereas responses to fertilization of associated biota (epiphytes and epifauna) were independent of whether clonal integration was maintained or severed.

Acknowledgements. This study was funded by the Spanish MINECO Plan Nacional (CGL2010-18545); F.T. was supported by the MINECO Ramón y Cajal program. We thank T. Sánchez and H. Hernández for their help during fieldwork, as well as Dr. J. J. Santana for help during chemical procedures and R. Riera (CIMA Canarias) for epifaunal identification. Anonymous reviewers provided valuable comments that improved a previous draft.

\section{LITERATURE CITED}

Anderson MJ (2001) A new method for non-parametric multivariate analysis of variance. Austral Ecol 26:32-46

- Antón A, Cebrián J, Heck K, Duarte CM, Sheehan KL, Miller MEC, Foster CD (2011) Decoupled effects (positive to negative) of nutrient enrichment on ecosystem services. Ecol Appl 21:991-1009

> Attrill MJ, Depledge MH (1997) Community and population indicators of ecosystem health: targeting links between levels of biological organization. Aquat Toxicol 38: 183-197

> Barberá C, Tuya F, Boyra A, Sánchez-Jerez P, Blanch I, Haroun RJ (2005) Spatial variation in the structural parameters of Cymodocea nodosa seagrass meadows in the Canary Islands: a multiscaled approach. Bot Mar 48: 122-126

> Bostrom C, Bonsdorff E, Kangas P, Norkko A (2002) Longterm changes of a brackish-water eelgrass (Zostera marina L.) community indicate effects of coastal eutrophication. Estuar Coast Shelf Sci 55:795-804

> Brearley A, Kendrick AJ, Walker D (2008) How does burrowing by the isopod Limnoria agrostica (Crustacea: Limnoriidae) affect the leaf canopy of the southern Australian seagrass Amphibolis griffithii? Mar Biol 156:65-77

Bryars S, Collings G, Miller D (2011) Nutrient exposure cause epiphytic changes and coincident declines in two temperate Australian seagrasses. Mar Ecol Prog Ser 441: 89-103

> Burkholder JM, Mason KM, Glasgow HB Jr (1992) Water column nitrate enrichment promotes decline of eelgrass Zostera marina: evidence from seasonal mesocosm experiments. Mar Ecol Prog Ser 81:163-178

Burkholder JM, Glasgow HB Jr, Cooke JE (1994) Comparative effects of water-column nitrate enrichment on eelgrass Zostera marina, shoalgrass Halodule wrightii, and widgeongrass Ruppia maritima. Mar Ecol Prog Ser 105: 121-138

Burkholder JM, Tomasko D, Touchette BW (2007) Seagrasses and eutrophication. J Exp Mar Biol Ecol 350: 46-72

> Cabaço S, Santos R (2007) Effects of burial and erosion on the seagrass Zostera noltii. J Exp Mar Biol Ecol 340:204-212

Cabaço S, Machías R, Viera V, Santos R (2008) Impacts of urban wastewater discharge on seagrass meadows (Zostera noltii). Estuar Coast Shelf Sci 78:1-13

Castejón-Silvo I, Terrados J, Domínguez M, Morales-Nin B (2012a) Epiphyte response to in situ manipulation of nutrient availability and fish presence in a Posidonia oceanica (L.) Delile meadow. Hydrobiologia 696:159-170

> Castejón-Silvo I, Domínguez M, Terrados J, Tomás F, Morales-Nin B (2012b) Invertebrate response to nutrientdriven epiphytic load increase in Posidonia oceanica meadows. Estuar Coast Shelf Sci 112:225-235

Duarte CM (1995) Submerged aquatic vegetation in relation to different nutrient regimes. Ophelia 41:87-112

> Espino F, Tuya F, Brito A, Haroun RJ (2011) Ichthyofauna associated with Cymodocea nodosa meadows in the Canarian Archipelago (central eastern Atlantic): community structure and nursery role. Cienc Mar 37:157-174

- Fourqurean JW, Zieman JC, Powell GVN (1992) Phosphorus limitation of primary production in Florida Bay: evidence from $\mathrm{C}: \mathrm{N}: \mathrm{P}$ ratios of the dominant seagrass Thalassia testudium. Limnol Oceanogr 37:162-171

Gartner A, Lavery PS, McMahon K, Brearley A, Barwick H (2010). Light reductions drive macroinvertebrate changes in Amphibolis griffithii seagrass habitat. Mar Ecol Prog Ser 401:87-100

> Gartner A, Tuya F, Lavery PS, McMahon K (2013) Habitat preferences of macroinvertebrate fauna among seagrasses with varying structural forms. J Exp Mar Biol Ecol 439:143-151

Gil M, Armitage AR, Fourqurean JW (2006) Nutrient impacts on epifaunal density and species composition in a subtropical seagrass bed. Hydrobiologia 569:437-447

- Goecker ME, Heck KL Jr, Valentine JF (2005) Effects of nitrogen concentrations in turtlegrass Thalassia testudinum on consumption by the bucktooth parrotfish Sparisoma radians. Mar Ecol Prog Ser 286:239-248

González JA (1990) Biología y pesquería de la vieja (Sparisoma cretense) en Canarias. PhD thesis. Universidad de La Laguna, Tenerife

- Hauxwell J, Cebrián J, Valiela I (2003) Eelgrass Zostera marina loss in temperate estuaries: relationship to landderived nitrogen loads and effect of light limitation imposed by algae. Mar Ecol Prog Ser 247:59-73

> Heck KL Jr, Valentine JF (2007) The primacy of top-down effects in shallow benthic ecosystems. Estuar Coast 30: 371-381

> Heck KL Jr, Valentine JF, Pennock JR, Chaplin G, Spitzer PM (2006) Effects of nutrient enrichment and grazing on shoalgrass Halodule wrightii and its epiphytes: results of a field experiment. Mar Ecol Prog Ser 326:145-156

Hemminga MA, Duarte CM (2000) Seagrass Ecology. Cambridge University Press, Cambridge

Hughes AR, Bando KJ, Rodriguez LF, Williams SL (2004) Relative effects of grazers and nutrients on seagrasses: a meta-analysis approach. Mar Ecol Prog Ser 282:87-99

Hughes AR, Williams SL, Duarte CM, Heck KL, Waycott M (2009) Associations of concern: Declining seagrasses and threatened dependent species. Front Ecol Environ 7: 242-246

> Lee KS, Short FT, Burdick DM (2004) Development of a nutrient pollution indicator using the seagrass, Zostera marina, along nutrient gradients in three New England estuaries. Aquat Bot 78:197-216

> Leoni V, Vela A, Pasqualini V, Pergent-Martini C, Pergent G (2008) Effects of experimental reduction of light and nutrient enrichments ( $\mathrm{N}$ and $\mathrm{P}$ ) on seagrasses: a review. Aquat Conserv 18:202-220

Marbà N, Hemminga MA, Mateo MA, Duarte CM, Mass YEM, Terrados J, Gacia E (2002) Carbon and nitrogen 
translocation between seagrass ramets. Mar Ecol Prog Ser 226:287-300

Marco-Méndez C, Prado P, Heck KL, Cebrián J, SánchezLizaso JL (2012) Epiphytes mediate the trophic role of sea urchins in Thalassia testudinum seagrass beds. Mar Ecol Prog Ser 460:91-100

Mascaró O, Oliva S, Pérez M, Romero R (2009) Spatial variability in ecological attributes of the seagrass Cymodocea nodosa. Bot Mar 52:429-438

Nielsen SL, Pedersen MF (2000) Growth, photosynthesis and nutrient content of seedlings and mature plants of Cymodocea nodosa - the importance of clonal integration. Aquat Bot 68:265-271

Oliva S, Mascaró O, Llagostera I, Pérez M, Romero J (2012) Selection of metrics based on the seagrass Cymodocea nodosa and development of a biotic index (CYMOX) for assessing ecological status of coastal and transitional waters. Estuar Coast Shelf Sci 114:7-17

Prado P, Romero J, Alcoverro T (2010) Nutrient status, plant availability and seasonal forcing mediate fish herbivory in temperate seagrass beds. Mar Ecol Prog Ser 409: 229-239

Short FT, Wyllie-Echeverria S (1996) Natural and humaninduced disturbance of seagrasses. Environ Conserv 23: $17-27$

Sterner RW, Elser JJ (2002) Ecological stoichiometry: the biology of elements from molecules to biosphere. Princeton University Press, Princeton, NJ

Terrados J, Duarte CM, Kenworthy WJ (1997) Experimental evidence for apical dominance in the seagrass Cymodocea nodosa. Mar Ecol Prog Ser 148:263-268

Thomsen MS, Wernberg T, Altieri A, Tuya F and others (2010) Habitat cascades: the conceptual context and global relevance of facilitation cascades via habitat formation and modification. Integr Comp Biol 50:158-175

Tomasko D, Lapointe BE (1991) Productivity and biomass of Thalassia testudinum related to water column nutrient availability and epiphyte levels: field observations and experimental studies. Mar Ecol Prog Ser 75:9-17

Editorial responsibility: Kenneth Heck Jr., Dauphin Island, Alabama, USA
Touchette BW, Burkholder JM, Glasgow HB (2003) Variations in eelgrass (Zostera marina L.) morphology and internal nutrient composition as influenced by increased temperature and water column nitrate. Estuaries 26: 142-155

Tuya F, Pérez J, Medina L, Luque A (2001) Variaciones estacionales de la macrofauna invertebrada de tres praderas marina de Cymodocea nodosa en Gran Canaria (centroeste del Océano Atlántico). Cienc Mar 27:223-234

Tuya F, Boyra A, Sánchez-Jerez P, Haroun RJ (2005) Multivariate analysis of the bentho-demersal ichthyofauna along soft bottoms of the Eastern Atlantic: comparison between unvegetated substrates, seagrass meadows and sandy bottoms beneath sea-cage fish farms. Mar Biol 147:1229-1237

Tuya F, Espino F, Terrados J (2013a) Preservation of seagrass clonal integration buffers against burial stress. J Exp Mar Biol Ecol 439:42-46

Tuya F, Hernández-Zerpa H, Espino F, Haroun RJ (2013b) Drastic decadal decline in the abundance of the seagrass Cymodocea nodosa at the island of Gran Canaria (eastern Atlantic): interactions with the green algae Caulerpa prolifera. Aquat Bot 105:1-6

Udy JW, Dennison WC (1997) Physiological responses of seagrasses used to identify anthropogenic nutrient inputs. Mar Freshw Res 48:605-614

Valentine JF, Heck KL (2001) The role of leaf nitrogen content in determining turtlegrass (Thalassia testudinum) grazing by a generalized herbivore in the northeastern Gulf of Mexico. J Exp Mar Biol Ecol 258:65-86

- Waycott M, Duarte C, Carruthers TJB, Orth RJ and others (2009) Accelerating loss of seagrasses across the globe threatens coastal ecosystems. Proc Natl Acad Sci USA 106:12377-12381

> Worm B, Reusch TBH, Lotke HK (2000) In situ nutrient enrichment: methods for marine benthic ecology. Int Rev Hydrobiol 85:359-375

> Yemm EW, Willis AJ (1954) The estimation of carbohydrates in plant extracts by anthrone. Biochem J 57:508-514

Submitted: January 21, 2013; Accepted: June 14, 2013

Proofs received from author(s): August 30, 2013 